SE D I M E N T A R Y STR U C T URE S A N D

T H E L O C A L I Z A T I O N A N D O X I D A T I O N

OF ORE A T THE PEANUT M INE.

MONTROSE COUNTY, COLORA D O

By Carl H, Roach and Mary E. Thompson

Trace Elements Investigations Report 512

UNITED STATES DEPARTMENT OF THE INTERIOR GEOLOGICAL SURVEY

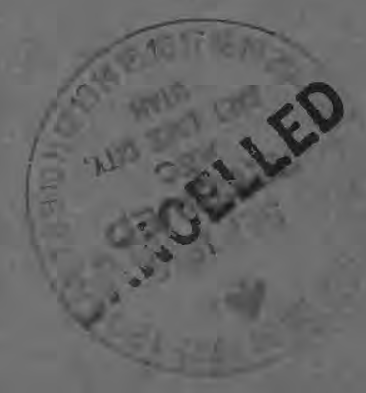





\section{UNITED STATES \\ DEPARTMENT OF THE INTERIOR \\ GEOLOGICAL SURVEY \\ WASHINGTON 25, D.C.}

AEC - 127/6

September 23, 1955

Mr. Rolvert $D$. Mininger, Assistant Director

Division of Raw Matorials

U. S. Atomic Feergr Cominission

Washington 25, D. C.

Dear Bob:

Transmitted herewith are three copies of IEI-512, "Sedimentary structures and the localisation and oxidation of ore at the Peanut mine, Montrose County, Colorado," by Carl H. Roach and Mary E. Thompson, July 1955.

We are asking Mr. Hosted to approve our plan to publish this report as a Geological Surver bulletin.

Sincerely yours,

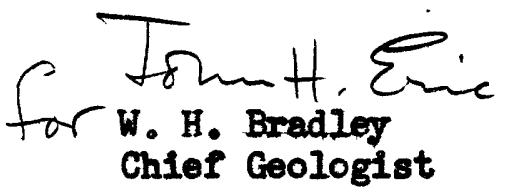



$(200)$

T67

no. 512

Geology and Mineralogy

This document consists of 15 pages.

Series A

UNITED STATES DEPARTMENT OF THE INTERIOR

GEOLOGICAL SURVEY

SEDIMENTARY STRUCTURES AND THE LOCALIZATION AND OXIDATION

OF ORE AT THE PEANUT MINE, MONTROSE COUNTY, COLORADO*

By

Carl H. Roach and Mary E. Thompson

July 1955

Trace Elements Investigations Report 512

This preliminary report is distributed without editorial and technical review for conformity with official standards and nomenclature. It is not for public inspection or quotation.

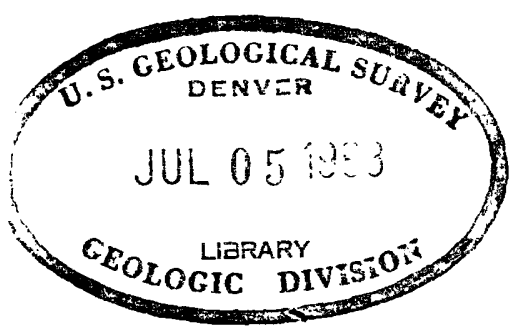

*This report concerns work done on behalf of the Division of Raw Materials of the U. S. Atomic Energy Commission. 
Distribution (Series A)

No, of copies

Argonne National Laboratory . 1

Atomic Energy Commission, Washington Battelle Memorial Institute, Columbus .

Carbide and Carbon Chemicals Company, $\mathrm{Y}-12$ Area

Division of Raw Materials, Albuquerque.

Division of Raw Materials, Butte .

Division of Raw Materials, Casper

Division of Raw Materials, Denver

Division of Raw Materials, Hot Springs

Division of Raw Materials, Ishpeming

Division of Raw Materials, Phoenix .

Division of Raw Materials, St. George

Division of Raw Materials, Salt Lake City

Division of Raw Materials, Washington .

Dow Chemical Company, Pittsburg

Exploration Division, Grand Junction Operations Office

Grand Junction Operations Office.

National Lead Company, Winchester

Technical Information Service, Oak Ridge

Tennessee Valley Authority, Wilson Dam

U. S. Geological Survey:

Fuels Branch, Washington. . . . . . . . . . . . . . . . . . . . 1

Geochemistry and Petrology Branch, Washington . . . . . . . . . . . . . . 4

Geophysics Branch, Washington

Mineral Classification Branch, Washington

Mineral Deposits Branch, Washington

E. H. Bailey, Menlo Park.

A. L. Brokaw, Grand Junction

N. M. Denson, Denver.

R. L. Griggs. Albuquerque

M. R. Klepper. Spokane

A. H. Koschmann, Denver

J. D. Love, Laramie

L. R. Page. Washington

Q. D. Singewald. Beltsville

A. E. Weissenborn, Spokane .

TEPCO, Denver.

TEPCO, RPS, Washington (including master) 
CONTENTS

Page

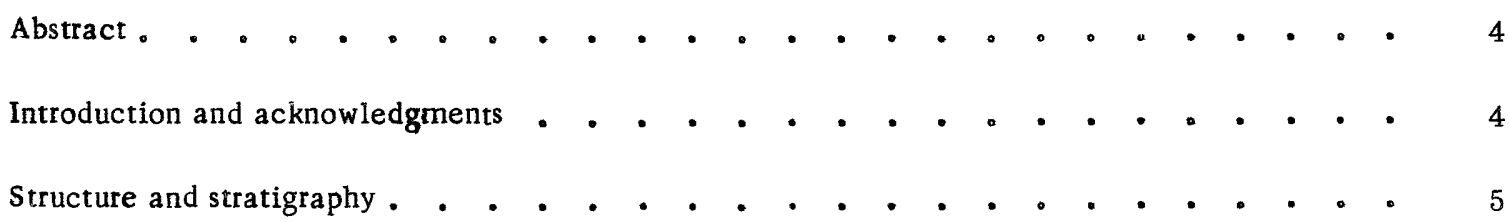

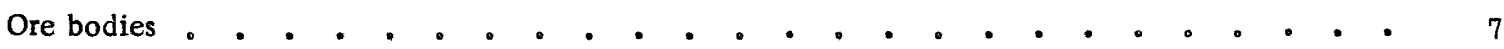

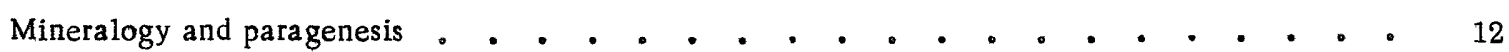

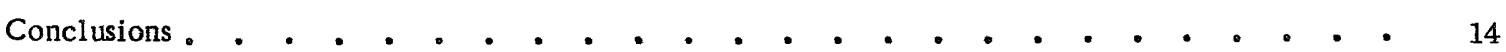

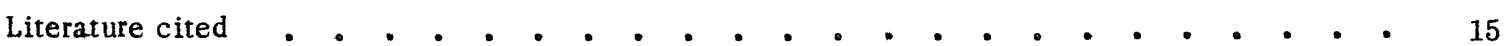

\section{ILLUSTRATIONS}

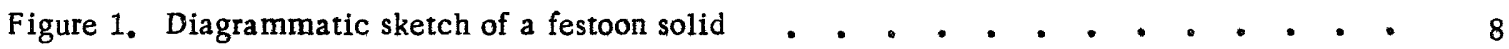

2. Various types of festoon solids and their relation to ore bodies . . . . . . $\quad 11$

3. Pattern of oxidation of a typical ore body in the Peanut mine, Montrose

County, Colorado . . . . . . . . . . . . . . . 


\title{
SEDIMENTARY STRUCTURES AND THE LOCALIZATION AND OXIDATION OF ORE AT THE PEANUT MINE, MONTROSE COUNTY, COLORADO
}

\author{
By Carl H. Roach and Mary E. Thompson
}

\begin{abstract}
At the Peanut mine in the Bull Canyon mining district, Montrose County, Colo, vanadium-uranium ore is mined from the Salt Wash member of the Morrison formation of Late Jurassic age. All of the ore bodies occur in the upper ore-bearing sandstone zone of the Salt Wash member. Ore bodies are relatively small and occur in clusters on the flanks of channels cut into a mudstone zone below. Most ore bodies conform in shape to the outlines of festoon "solids"; smaller ore bodies are restricted to the upper parts of festoon "solids". The festoon surfaces are relatively impermeable to ground water; many of the ore bodies are saturated with water perched above the basal surfaces of festoons.

The principal ore minerals are uraninite, coffinite, montroseite, and vanadiferous clays. Four new vanadium minerals occur in the ore. Molybdenite, digenite, and native selenium are present in addition to the normal suite of metallic minerals.

The upper parts of individual ore bodies are more oxidized than lower parts, therefore the hypothesis is offered that the less permeable festoon surfaces "trapped" the ore, and inhibit draining of ground water, thus protecting the lower parts of ore bodies from oxidation.
\end{abstract}

\section{INTRODUCTION AND ACKNOWLEDGMENTS}

The Peanut mine is in the Bull Canyon mining district, Montrose County, Colo., about 15 miles west of Naturita, Colo.

A detailed study of the geology of the Peanut mine was begun in February 1954, for the primary purpose of determining the trace element composition of the ore deposit. Secondary objectives were to determine (1) if trace element dispersion patterns are present that might be used as guides to ore, (2) possible structural controls of the ore bodies, and (3) the paragenesis of the ore minerals. 
The study of the mine included detailed mapping and extensive sampling of the ore and adjacent rock, as mining progressed. The mine was visited almost every day during the first year of the study。 Thin sections and polished sections were obtained for many of the samples. Preliminary results of the study reported in this paper indicate a definite relation between sedimentary structures of the host rock and the localization and oxidation of the ore bodies.

Mining on the Peanut claims was begun early in 1954 by the $J_{0} R_{\bullet}$ Simplot Mining Company of Boise, Idaho. In September 1954, the mine was sold to the Camoose Mines of America, Incorporated ${ }^{\circ}$ of New York. The managements of both these companies were very cooperative in permitting the extensive studies of the mine.

Thanks are due to the chemists and spectrographers at the Denver and the Washington laboratories of the U. S. Geological Survey, who analyzed samples from the Peanut mine, and to D. A. Jobin, U。 Geological Survey, who made permeability measurements of a number of samples.

The investigation is being made by the U. S. Geological Survey on behalf of the Raw Materials Division of the U. S. Atomic Energy Commission.

\section{STRUCTURE AND STRATIGRAPHY}

The Peanut mine is located along the axis of the Dry Creek Basin syncline which lies between the Paradox Valley and the Gypsum Valley salt anticlines (Cater, 1954). The rock strata are essentially horizontal in the vicinity of the mine.

The dissection of Bull Canyon has caused the regional water table to lower to a position several hundred feet below the ore horizon. This dissection, according to Fenneman (1931), began at, or soon after, the beginning of the Pleistocene. Water; now present in the Peanut mine is in small perched water tables.

Sedimentary rocks exposed in the vicinity of the mine range in age from Middle Jurassic to late Cretaceous. The formations in ascending order are the Jurassic Entrada sandstone, the Summerville formation, and Morrison formation and the Cretaceous Burro Canyon formation and Dakota sandstone. The Morrison formation of Late Jurassic age is composed of two members, the lower, called the Salt Wash member, and 
The Brushy Basin member consists of variegated mudstones with a few interstratified layers of sandstone and conglomerate. It is about 400 feet thick in the vicinity of the Peanut mine and has an indistinct contact with the underlying Salt Wash member.

The Salt Wash member is about 350 feet thick near the Peanut mine. It consists of a series of sandstone layers separated by red and green mudstone beds. Regionally, the sandstone layers pinch out or coalesce with other sandstone units. The top 40 to 60 feet of the Salt Wash member consists of a series of broad discontinuous sandstone lenses and thin discontinuous layers of red and green mudstone. All of the ore bodies at the Peanut mine occur in this stratigraphic zone, which is commonly referred to as the ore-bearing sandstone. The ore-bearing sandstone is underlain by a mudstone layer 20 to 40 feet thick. Throughout most of the area the ore-bearing sandstone has a nearly uniform thickness of about 40 feet. Locally, it may thicken abruptly to 60 feet or more where channels are cut into the underlying mudstone. Much of the ore-bearing sandstone is flat bedded or gently crossbedded, but in the vicinity of a channel the crossbedding is more complex. On the flanks of the channels a particular type of crossbedding. known as festoon cross-lamination. is especially well developed.

According to Knight $(1929 ; 1930)$. festoons are the results of (1) the erosion of plunging troughs having the shape of a quadrant. or segment. - / of an elongate ellipsoid. (2) the filling of the troughs by clastic

_ Underlined words added by the authors.

sediments, commonly in thin laminae which generally conform to the shape of the trough floors, and (3) the partial destruction, in differing degrees, of the filling laminae by subsequent erosion, producing younger troughs which intersect the older troughs.

Knight believes the festoons were created by oscillating currents in comparatively shallow water. Probably the same stream that cut the channel into the mudstone layer. at a later stage in its history and after some aggradation, created the festoon cross-laminations, 
The geometric features produced by the intersections of groups of festoons are many and complex. The feature shown diagrammatically on figure 1 is produced by the intersection of three festoons and is more common than any other. Festoon 1 has been intersected by the later formation of festoon 2 and both have been intersected and partially destroyed. by the formation of festoon 3.

For convenience in discussion, this physical feature as shown in figure 1 , will be referred to as a festoon solid, i. e.. a solid bounded by three festoon surfaces. The lower erosion surface, or trough floor, of the festoon solid will be called a basal festoon surface, and the mass of sandstone above the basal festoon surface and terminated by the upper festoon surfaces will be called the festoon fill. Less prominent cross-laminations occur in the festoon fill. They are related to the basal festoon surface, and will be referred to as secondorder festoon surfaces.

The festoon surfaces are relatively impermeable. Water perched above a basal festoon surface will drain only after the festoon surface is punctured by mining activities. A number of permeability measurements were made on samples taken from an ore-barren festoon solid. Samples from the center of the festoon solid showed relatively small differences in permeability measured parallel to and normal to the bedding planes. Samples taken from close to the festoon surface showed marked differences in permeability in the two directions; some samples were more than 100 times more permeable parallel to the bedding than normal to it. A thin clay seam is commonly present along the festoon surface; this clay is seldom retained when the core is prepared for the permeability measurement; therefore, the relative impermeability may actually be much greater through the festoon surface than measurements indicate on available samples.

\section{ORE BODIES}

Most of the ore bodies at the Peanut mine occur as clusters in the lower part of the ore-bearing sandstone zone, but small bodies of mineralized rock also occur in a zone 5 to 15 feet above the principal ore-bearing zone. 


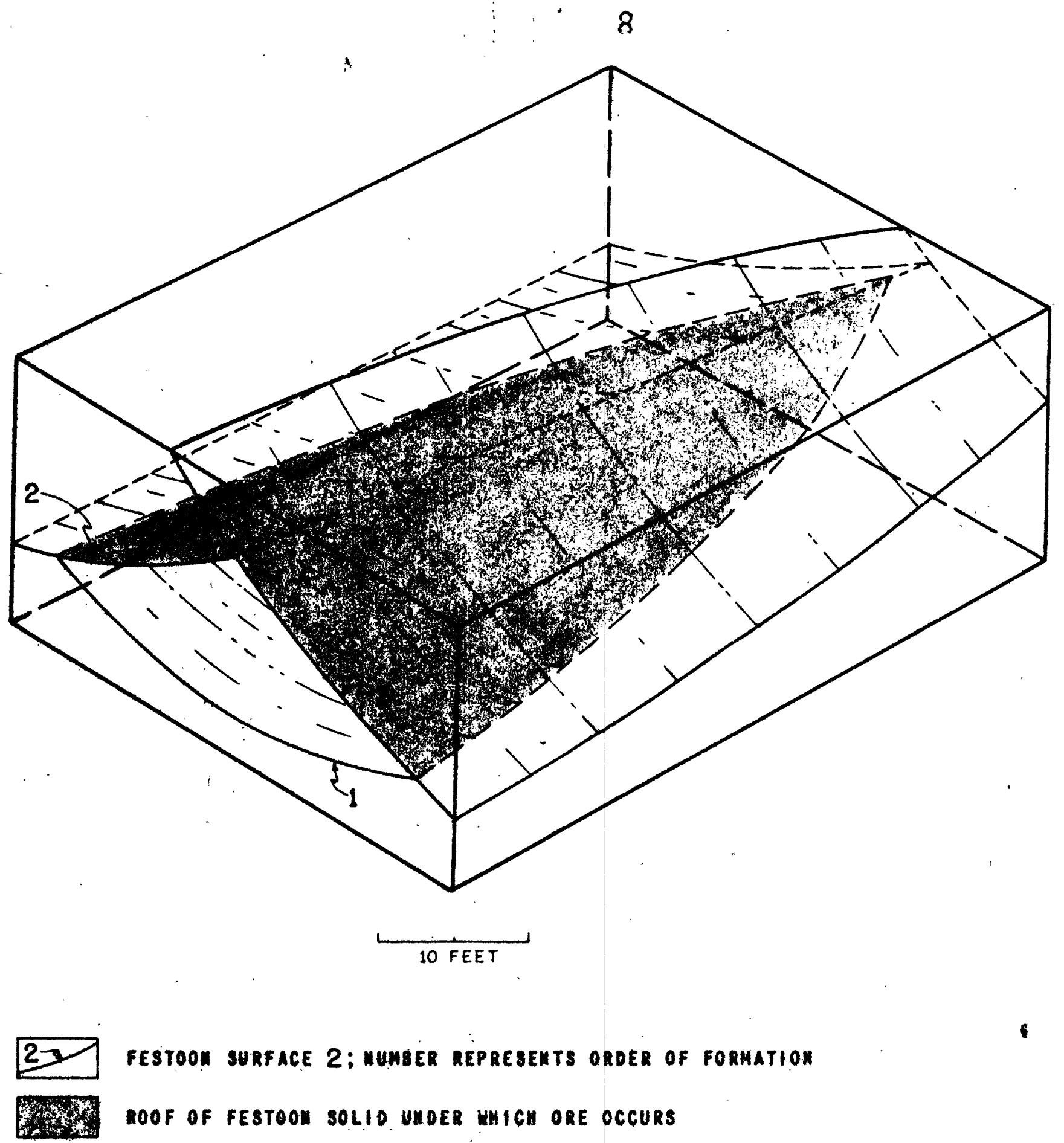


The ore bodies are lenticular in shape and tend to pinch out rapidly. Some closely spaced lenticular masses of ore coalesce into a single ore body. The average ore body is about 50 feet long, 20 feet wide, and varies in thickness from a few inches at the edges to 6 or more feet at the thickest part. Contacts between mineralized rock and barren rock are very sharp, and in general correspond to the major changes of direction of bedding, i. $e_{0}$, the cross-laminated festoon surfaces.

A few ore bodies in the mine have the shape of rolls (Fischer, 1942); the contact between mineralized and barren rock curves across the bedding. The contact is well defined and may be mapped as a continuous surface for a distance of 20 feet or more. Rolls trend about $\mathrm{S}_{0} 70^{\circ}$ to $80^{\circ} \mathrm{E}_{0}$. and conform to the trend of rolls mapped in other mines in the district.

The average vanadium-uranium ratio of the ore bodies is about 9 to 1 . Assays of a number of drill cores of ore bodies show an average grade of 0.5 percent $U$ and 4.5 percent $V_{0}$ The average vanadium-uranium ratio of the smaller bodies of mineralized rock that occupy a stratigraphically higher position is about 4 to 1 . Assays of a few drill cores of these bodies show about 1 percent $U$ and about 4 percent $V$. The grade of ore within one ore body does not vary significantly, except where oxidation along fractures may have leached the ore. Local concentrations of higher grade uranium-bearing material are associated with organic matter. Sulfide minerals accompanying the ore tend to concentrate at the base of ore bodies.

The shapes of all ore bodies, except those few that make rolls, conform to the shapes of festoon solids whose surfaces mark the boundaries of the ore. Larger ore bodies nearly fill a festoon solid, but most of the ore bodies are smaller and are restricted to the upper parts of the structure.

The upper contacts of ore with barren rock almost invariably correspond to festoon surfaces. (The few exceptions are the ore bodies in the shape of rolls, ) Ore bodies are restricted to those festoon solids, or parts of festoon solids, whose upper surfaces have structural closure. The lenticular shape of the ore body is determined by the shape of the festoon solid in which it occurs and the amount of structural closure formed by the upper surfaces of the festoon solid. The simple lenticular shape of an ore body may be complicated by the presence of "splits" of barren rock penetrating the ore body. These "splits" correspond to second-order festoon surfaces. 
Many variations of the symmetrical festoon solid are present in the mine. Some of the most common of these are shown in figure 2. Figure 2A shows a cross section of a symmetrical festoon solid, with mineralized rock in the upper part. Figure $2 B$ shows a longitudinal section of the same festoon solid. The mineralized rock extends downward no further than the structural closure of the upper festoon surfaces. Figure $2 \mathrm{~B}$ also shows the festoon solid as completely closed to the right, whereas to the left the festoon surfaces gradually flatten in dip. and either lose definition, or are truncated by other festoon surfaces.

Smaller bodies of mineralized rock that occur stratigraphically 5 to 15 feet above the ore zone commonly show a "satellite" relation to larger bodies of ore that are enclosed (in part) under the same through-going festoon surface. Such a relation is shown in figure 2 C.

Some festoon solids are skewed rather than symmetrical, but in those too, the ore extends downward only as far as the festoon solid has closure, as shown in figure $2 \mathrm{D}$.

Figure 2E shows a generalized cross section of a cluster of closely spaced or coalescing ore bodies contained in a complex group of interpenetrating festoon solids. It can be seen from this figure that prediction of the location and extent of ore bodies is difficult or impossible without recognition of the relation of ore bodies to the festoon surfaces. A positive result of this study has been the adaptation of mining methods to the controlling influences of the festoon surfaces, and a number of ore bodies have been discovered that might otherwise have been missed.

The position of ore bodies under relatively impermeable surfaces is similar to petroleum occurrences in anticlinal reservoirs under impermeable cap rocks. A density stratification of the ore solutions with the ground water may have been responsible for this relation. A possible explanation for the precipitation of the ore is that ore solutions moving through the aquifer (the upper ore-bearing sandstone of the Salt Wash member), were slowed when they entered the festoon structures. They passed through the festoon surfaces, but much more slowly than they had passed through the even-bedded parts of the Salt Wash member. The slower rate of flow may have caused the precipitation of the ore. 


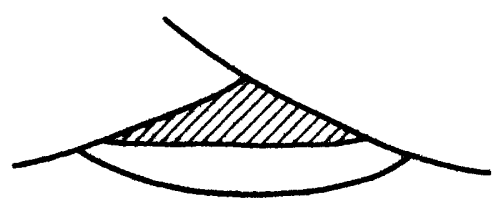

A. SYKMETRICAL FESTOON SOLIO CROSS SECTION

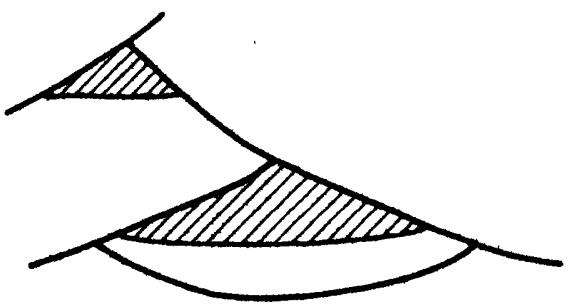

C. ORE BODY II FESTOON SOLIO WITH SATELLITE" CROSS SECTION f

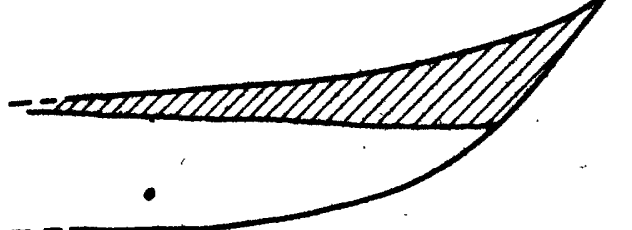

B. SYMMETRICAL FESTOON SOLID LONGI TUDIMAL SECTION

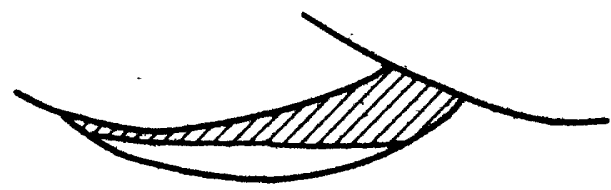

D. SKENED FESTOON SOLIO CROSS SECTION

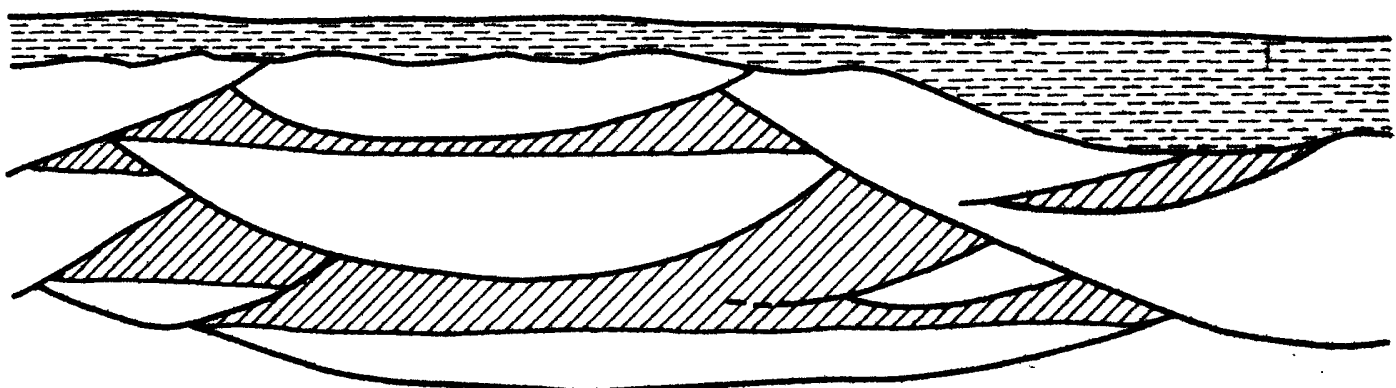

E. COALESGIMG FESTOONS; COMPOUNO ORE BOOIES CROSS SECTION

ए BARREM SAMOSTOME Elala ORE $E=3$ MUOstore 10 FEET

Figure 2. VARIOUS TYPES OF FESTOON: SOLIDS AND THEIR RELATION: TO ORE BODIES: 
Most of the ore bodies at the Peanut mine are unoxidized. Some oxidation has taken place but is common-t ly restricted to zones along fractures or to the upper parts of ore bodies. One partly oxidized ore body was sampled in detail. The pattern of oxidation is shown in figure 3. The lower part of the ore is unoxidized and contains montroseite, vanadiferous clays, uraninite, and coffinite. Doloresite and other tetravalent vanadium minerals occur as fracture coatings in the montroseite-bearing sandstone and at the top of the unoxidized ore. Abundant crystals of native selenium are also present in the fractures. Melanovanadite and other vanadyl vanadatos occur slightly higher in the ore body than the tetravalent vanadium minerals. At the top of the ore body are tyuyamunite and pascoite. The unmineralized sandstone around the most oxidized part of the ore body is stained by limonite.

The approximate level of the water perched above the basal festoon surface is indicated in figure 3 . Montroseite containing essentially all trivalent vanadium was collected from beneath the water level in one ore body. and after a few months in the laboratory, the material had oxidized almost completely to $\mathrm{V}^{4}$. indicating that the presence of standing water in the festoon solid prevented oxidation of the montroseite in place.

The controlling influence of the festoon cross-laminations on the oxidation of the ore is indirect. After the lowering of the regional water table, the relative impermeability of the basal festoon surfaces caused the formation of perched water tables. The standing water saturating the ore bodies prevented their oxidation or restricted the oxidation that took place to the upper parts of the ore bodies.

\section{MINERALOGY AND PARAGENESIS}

Ore minerals impregnate sandstone and replace coalified wood. The highest grade uranium-bearing samples are associated with coalified wood. The chief uranium minerals are uraninite and coffinite; the most abundant vanadium minerals are montroseite and vanadiferous clays.

Vanadiferous clays occur as ill-defined masses interstitial to the quartz grains in the sandstone. Montroseite occurs as euhedral, lath-shaped crystals radiating from quartz grains. Commonly, the montroseite crystals are partly or completely surrounded by secondary quartz overgrowths. Montroseite associated with 


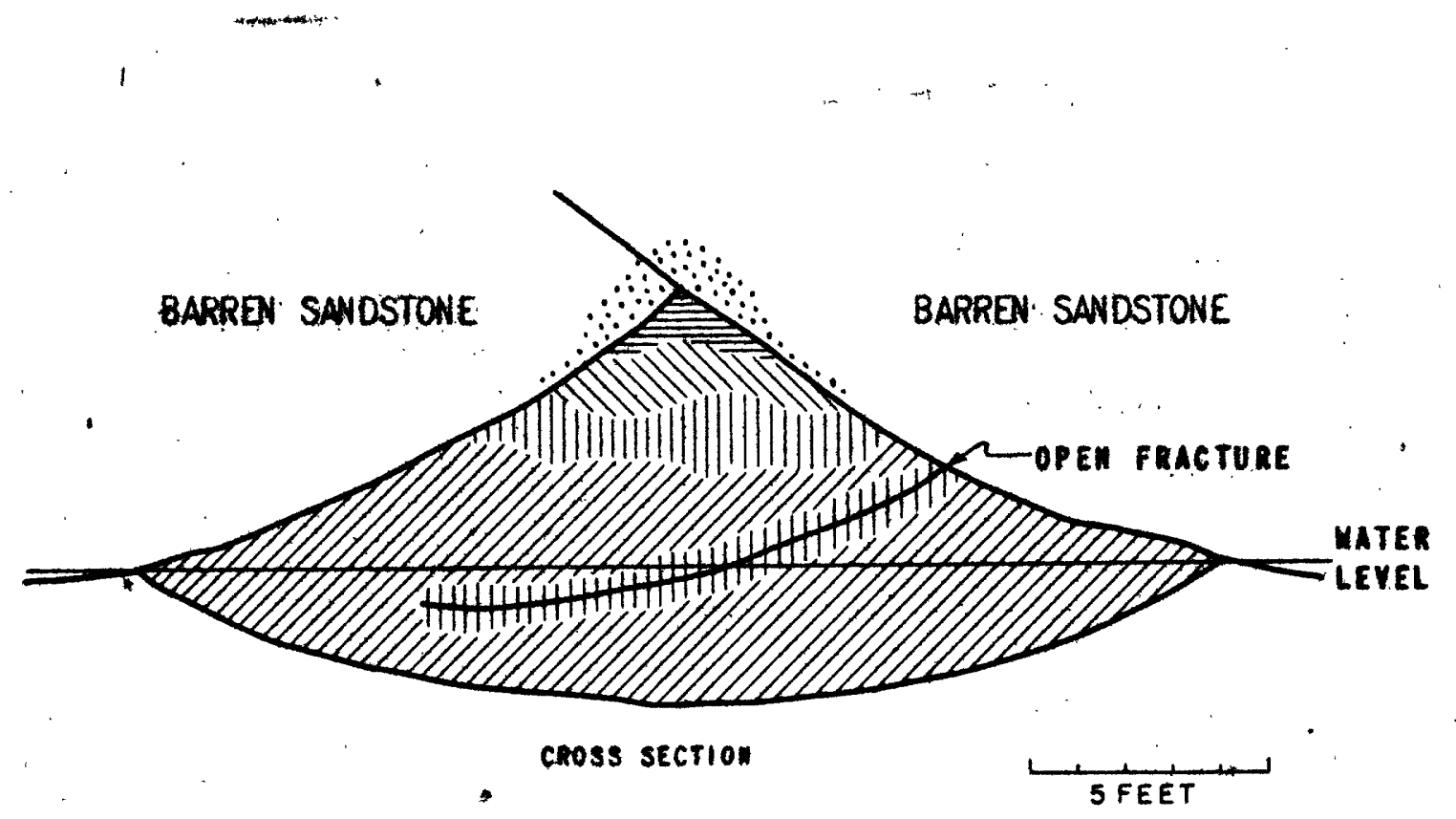

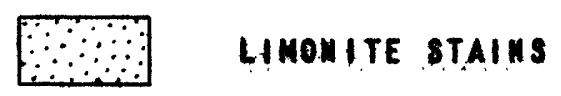

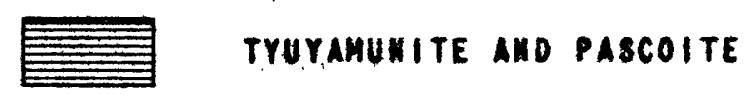

MIIUN $v^{4}-r^{5}$ MIMERALS

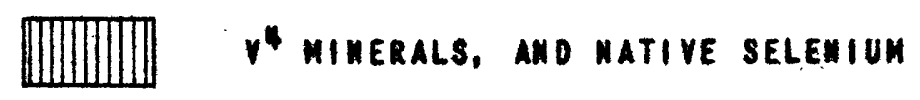

EDIITA unOXIDIzEo ORE

- LEVEL OF MATER BEFORE MINIWE

Figure 3. PATERW OF OXIDATION OF A TYPICAL ORE BOOY

IN. THE PEANUT MIME, MONTROSE COLANT,; COLORADO 
wood occurs both as lath-shaped crystals and as botryoidal masses. In sandstone ore, uraninite and coffinite are finely divided and are not visible as discrete minerals. Polished section studies show that uraminite and coffinite in coalified wood replace cell walls and cell interiors selectively。

Montroseite in coalified wood is commonly associated with pyrite and yellow barite. Sulphide minerals found in small amounts with the unoxidized ore are pyrite, marcasite, chalcopyrite, chalcocite, molybdenite, galena, and sphalerite. Studies of polished sections show that a small amount of digenite is associated with the chalcocite.

It is not certain whether doloresite is at primary ore mineral or an oxidation product of montroseite. It is commonly found intergrown with the tetravalent phase of montroseite. It also occurs coating and partly recementing fractures in montroseite-bearing sandstone. Also occurring as fracture coatings are two undescribed tetravalent vanadium minerals. Melanovanadite and abundant crystals of native selenium are commonly associated with the doloresite and the two undescribed vanadium minerals.

Melanovanadite occurs more commonly in a somewhat more oxidized zone with two undescribed vanadyl vanadates, and with corvusite.

The completely oxidized ore contains tyuyamunite, pascoite, and corvusite. Small amounts of gypsum occur with barite and carbonaceous material in the oxidized ore. The unmineralized sandstone around the oxidized part of an ore body is stained by limonite, which is formed from alteration of sulfides. Small amounts of malachite presumably derived from alteration of copper sulfides occur with the limonite.

\section{CONCLUSIONS}

Ore bodies are concentrated on the flanks of channels, where festoon cross-laminations are best developed. Contacts between mineralized and barren rock are sharp, and in all ore bodies, except rolls, they correspond to festoon surfaces. Ore bodies are contained within festoon solids and are found only in the part of the festoon solid having structural closure. This fact is verified by observation of many separate ore bodies in the Peanut mine, and the same relationship has been observed in other mines in the area. Permqability measurements and the presence of perched water tables indicate that the festoon surfaces are relatively impermeable. Oxidation of the ore bodies has been inhibited by the presence of the perched water tables 
The sedimentary structures of the host rock, in particular the festoon cross-laminations, have exerted a controlling influence on the localization of the ore and have determined the pattern of oxidation of individual ore bodies.

\section{LITERATURE CITED}

Cater, F. W. . 1954, Geologic map and geology of the Bull Canyon quadrangle, Colorado: U. S. Geol. Survey Geologic Quadrangle Maps of the United States.

Fenneman, N. M. , 1931, Physiography of western United States, 534 p. New York, McGraw-Hill Book Co. Inc.

Fischer, R. P., 1942, Vanadium deposits of Colorado and Utah: U. S. Geol. Survey Bull. 936-P.

Knight, S。 H., 1929, The Fountain and Casper formations of the Laramie Basin; A study on genesis of sediments: Univ, of Wyoming. Pub. Sci., Geol., v. 1, p. 1-82.

1930, Festoon cross-1amination (abs.): Geol. Soc. America Bull., v. 41, p。 86; Pan-Am. Geologist, v. 53, p. 130 . 


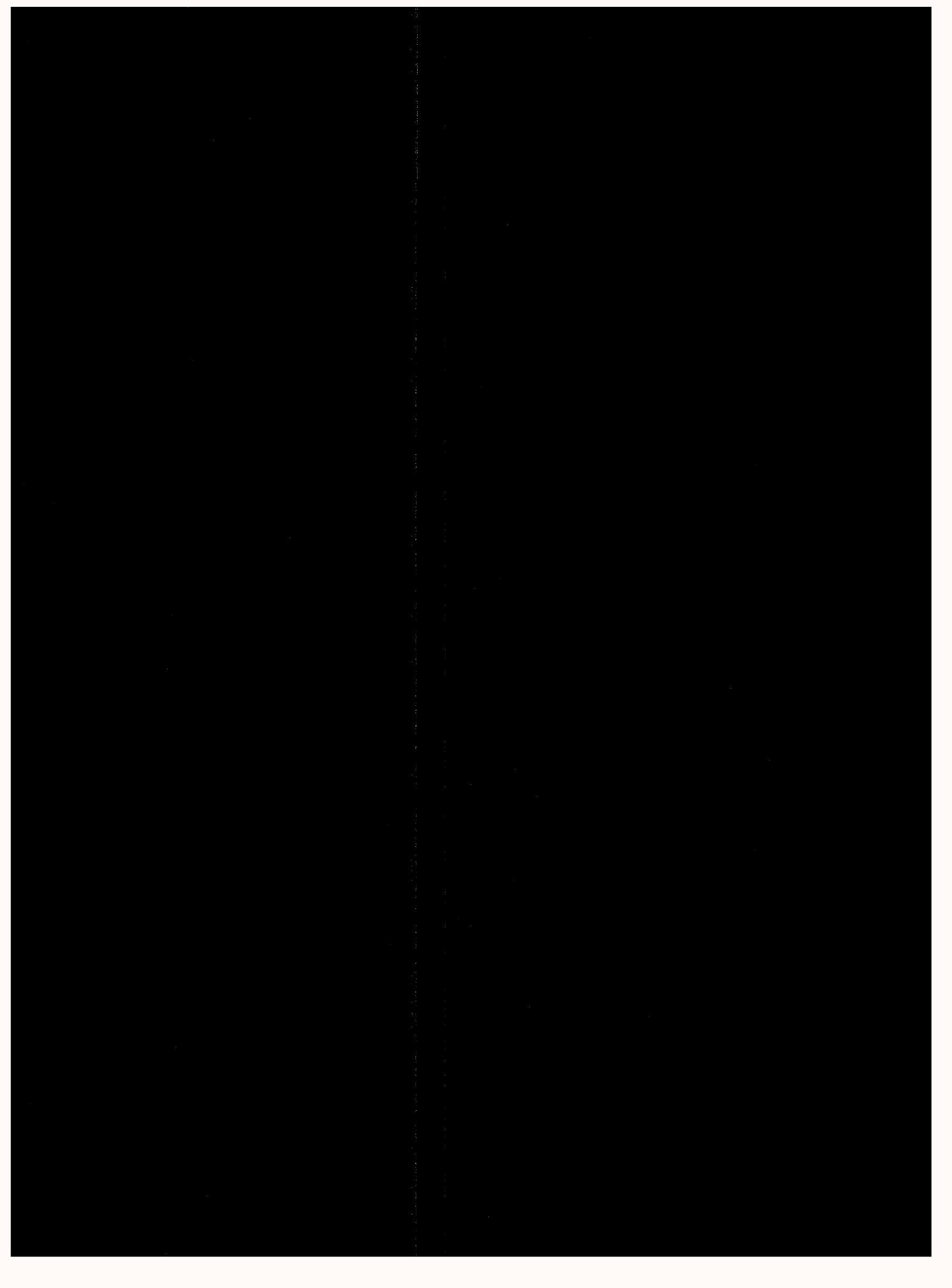

